\title{
A vállalkozás folytatása számviteli alapelv érvényesülésének vizsgálata az önkormányzati tulajdonú gazdasági társaságoknál
}

\section{Analysis of the Enforcement of the Principle of Going Concern by Companies in Local Government Ownership Through Bankruptcy Models}

ÖSSZEFOGLALÁS

A tanulmány olyan önkormányzati vállalatokat vizsgál csôdelôrejelzési modellek segítségével, melyek 2011 és 2016 között fejezték be tevékenységüket. A vizsgálat végén arra kaptunk választ, hogy a szakirodalomból ismert csôdmodellek, illetve a likviditási és tôkeerôsségi mutatók mennyiben jelezték előre a fizetésképtelenség bekövetkezésének valószínúségét. A vizsgálatból jól látható, hogy a vizsgált vállalkozások 20-25 százalékánál nem a fizetési nehézségek miatt szúnt meg a vállalkozási tevékenység, hanem a tulajdonosi döntés alapján.

Journal of Economic Literature (JEL) kódok: G33, H72

Kulcsszavak: közüzemi vállalatok, csôdmodellek, likviditás, tôkeerôsségi ráta

\section{Summary}

Using various bankruptcy prediction models, the paper analyses local governmentowned companies that stopped operation between 2011 and 2016. The accuracy of predicting the probability of bankruptcy by the bankruptcy models known from the literature (Altman's model, models developed for Czech and Brazilian companies etc.) and by the liquidity ratio and equity ratio is determined. It is concluded that 2025 percent of the companies stopped their business activity for reasons other than payment difficulties.

Journal of Economic Literature (JEL) codes: G33, H72

Keywords: public utility companies, bankruptcy models, liquidity, equity ratio

Molnár Petronella, tudományos kutató, Nemzeti Közszolgálati Egyetem, Közpénzügyi Kutatóintézet, PhD-hallgató, Szent István Egyetem (Molnar.Petronella@uni-nke.hu). 


\section{Tudományos múhely}

\section{BevezetéS}

A közfeladatot ellátó gazdasági társaságoktól különösen elvárt a rentábilis és hatékony múködés, ugyanis közpénzekkel gazdálkodnak a feladataik ellátása során. Ezen cégek felelnek az adott településen élôk életminôségéért, így náluk is mindenkor érvényesülnie kell a vállalkozás folytatása számviteli alapelvnek. A tanulmány olyan önkormányzati tulajdonú közüzemi vállalatokat vizsgál, melyek 2011 és 2016 közötti idôszakban vállalkozási tevékenységüket megszüntették, azaz ahol nem érvényesült az elóbb említett számviteli alapelv.

\section{ElméLETI HÁTTÉR}

Az önkormányzati vagyon nemzeti vagyonnak minôsül, amely vagyonnal, azaz a közpénzekkel az önkormányzati tulajdonú, közfeladatot ellátó gazdasági társaságok is gazdálkodnak (Lentner, 2013b). A közpénzek felhasználása során elvárt, hogy társadalmi haszna legyen (Németh-Kolozsi, 2015), önkormányzati tulajdonú cégek esetében ez a közszolgáltatások minôségét is jelenti (Hegedús, 2015). Amennyiben a helyhatóságok a közfeladatok ellátását a tulajdonukban lévố vállalatokra bízzák, akkor ezen vállalatoktól különösen elvárt a múködôképesség mindenkori fenntartása, a költséghatékony gazdálkodás, valamint a vállalkozás folytatása számviteli alapelvének érvényesülése (Hegedús-Zéman, 2016; Zéman, 2017; Lentner, 2013a). A közüzemi vállalatok múködésük során nem termelhetnek veszteséget, múködésük feltétele az eredményes gazdálkodás (Zéman-Tóth, 2015). A közszolgáltató tevékenységet végzô cégek esetében a vállalkozási tevékenység beszüntetése társadalmi érdekeket is sérthet, ezért is fontos a múködés során mindenkor szem előtt tartaniuk az egyik talán legfontosabb számviteli alapelvet, a vállalkozás folytatásának elvét (Lentner, 2015).
ANYAG ÉS MÓDSZer

Vizsgálatom középpontjába olyan önkormányzati tulajdonú gazdasági társaságok kerültek, melyek tevékenységüket véglegesen befejezték. A vizsgált cégek elemszáma 166 darab volt, azonban az alkalmazott modellekhez nem minden esetben álltak rendelkezésre a mutatószámok. A vizsgált hat év a tevékenység megszüntetésének az éve, illetve az azt megelőzô öt év (a tevékenység végleges beszüntetésének évét vettem a bázisévnek). A vizsgált cégek 2011 és 2016 között fejezték be a tevékenységüket.

A kutatás során Altman módosított csôdelôrejelzési modelljét, valamint az Altman-modell újraszámítása során keletkezett, a cseh Karas és szerzôtársai modelljét és a brazil számviteli szabványokra kialakított (Altmanmodellen alapuló) modelljét használtam.

Altman modellje (1968) a következôképpen néz ki:

$\mathrm{Z}=0,717 \mathrm{X}_{1}+0,847 \mathrm{X}_{2}+3,107 \mathrm{X}_{3}+0,42$ $\mathrm{X}_{4}+0,998 \mathrm{X}_{5}$; ahol

$$
\begin{aligned}
& \mathrm{X}_{1}=\frac{\text { nettó forgótóke }}{\text { összes eszköz }} \\
& \mathrm{X}_{2}=\frac{\text { visszatartott nyereség }}{\text { összes eszköz }} \\
& \mathrm{X}_{3}=\frac{\text { adó- és kamatfizetés elótti eredmény }}{\text { összes eszköz }} \\
& \mathrm{X}_{4}=\frac{\text { részuények könyv szerinti értéke }}{\text { adósság }} \\
& \mathrm{X}_{5}=\text { eszközarányos árbevétel }
\end{aligned}
$$

Karas és szerzôtársai (2013, 2017) az alábbi függvényt alkalmazták:

$\mathrm{Z}=0,33363 \mathrm{X}_{1}+0,29457 \mathrm{X}_{2}+2,73238$ $\mathrm{X}_{3}+0,12234 \mathrm{X}_{4}+0,00091 \mathrm{X}_{5}$

A brazil modell (Altman, 1993; Altman et al., 1979) alakja pedig a következó:

$\mathrm{Z}=1,44 \mathrm{X}_{1}+4,03 \mathrm{X}_{2}+2,25 \mathrm{X}_{3}+0,14 \mathrm{X}_{4}$ $+0,42 \mathrm{X}_{5}$

A vállalkozásokat elhelyezkedésük alapján területi kategóriákba soroltam, s a Chi² próbát elvégezve megállapítottam, hogy kimutatható-e szignifikáns összefüggés a területi elhelyezkedés és a csôdelôrejelzô 
modellek értékei között. A vizsgálat zárásaként megvizsgáltam a vállalatok vagyoni (tôkeerôsségi mutató) és likviditási (likviditási ráta) helyzetét (Béhm et al., 2016).

\section{A VIZSGÁLAT EREDMÉNYEI}

Az 1-3. táblázat az Altman-csôdelôrejelzési modell használatával kiszámított értékeket mutatja.

A modell szerint a vizsgált vállalkozásoknak a tevékenység beszüntetését megelózó 5. évben 43,1 százaléka került a csôdös kategóriába, míg 27,7 százaléka a szürkezónába, azaz a vállalatok 29,2 százalékánál a modell nem jelezte a csôd bekövetkezésének valószínúségét, a tevékenység megszüntetését. Ezen év modellértékei alapján a modell a megyei jogú városokban múködő cégek esetében jelezte elôre leginkább a csôd be- következésének valószínúségét (8,3 százalékot sorolt mindössze a túlélố kategóriába).

A következó évben - azaz a vállalkozási tevékenység befejezését megelôzô 4 . évben a modell már a fóvárosban tevékenykedô cégek esetében is nagymértékben jelezte a csôdkockázatot, a fôvárosi vállalkozások 71,4 százaléka csôdösnek minôsült, míg 14,3 százaléka a szürkezónába került. Ezen évben a vizsgált társaságok több mint 50 százaléka csôdösnek minôsült a modell értékei szerint.

A tevékenység megszüntetését megelózó 2. és 3. évben a modell kedvezóbb képet mutatott az elôzô évhez képest (2. táblázat). A vizsgált gazdasági társaságok 50 százaléka került a csốdös kategóriába, míg 25-29 százalékuk a szürkezónába. Ha a településkategória szerinti besorolást megvizsgáljuk, elmondhatjuk, hogy a legnagyobb arányban (több mint 60 százalék) a megyei jogú vá-

1. táblázat: Az Altman-modell értékei a bázisév-5. és-4. évben

\begin{tabular}{|c|c|c|c|c|c|c|c|c|c|c|}
\hline & \multicolumn{3}{|c|}{$\begin{array}{c}\text { Altman-modell, bázisév } \\
-5 \text {. év }\end{array}$} & \multirow{2}{*}{$\begin{array}{l}\text { Össze- } \\
\text { sen }\end{array}$} & \multicolumn{3}{|c|}{$\begin{array}{c}\text { Altman-modell, bázisév } \\
-4 . \text { év }\end{array}$} & \multirow{2}{*}{$\begin{array}{l}\text { Össze- } \\
\text { sen }\end{array}$} \\
\hline & & & csôdös & $\begin{array}{l}\text { szürke- } \\
\text { zóna }\end{array}$ & túlélő & & csôdös & $\begin{array}{l}\text { szürke- } \\
\text { zóna }\end{array}$ & túlélő & \\
\hline \multirow{8}{*}{ 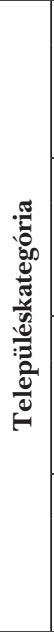 } & \multirow[b]{2}{*}{ 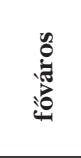 } & Cégek száma & 3 & 1 & 3 & 7 & 5 & 1 & 1 & 7 \\
\hline & & $\begin{array}{l}\text { Településkate- } \\
\text { górián belüli } \\
\text { megoszlás }\end{array}$ & $42,9 \%$ & $14,3 \%$ & $42,9 \%$ & $100,0 \%$ & $71,4 \%$ & $14,3 \%$ & $14,3 \%$ & $100,0 \%$ \\
\hline & \multirow[b]{2}{*}{ 望 } & Cégek száma & 7 & 10 & 6 & 23 & 13 & 6 & 8 & 27 \\
\hline & & $\begin{array}{l}\text { Településkate- } \\
\text { górián belüli } \\
\text { megoszlás }\end{array}$ & $30,4 \%$ & $43,5 \%$ & $26,1 \%$ & $100,0 \%$ & $48,1 \%$ & $22,2 \%$ & $29,6 \%$ & $100,0 \%$ \\
\hline & \multirow{2}{*}{ 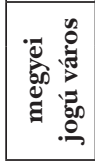 } & Cégek száma & 9 & 2 & 1 & 12 & 11 & 2 & 1 & 14 \\
\hline & & $\begin{array}{l}\text { Településkate- } \\
\text { górián belüli } \\
\text { megoszlás }\end{array}$ & $75,0 \%$ & $16,7 \%$ & $8,3 \%$ & $100,0 \%$ & $78,6 \%$ & $14,3 \%$ & $7,1 \%$ & $100,0 \%$ \\
\hline & \multirow[b]{2}{*}{ 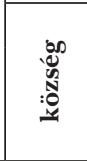 } & Cégek száma & 9 & 5 & 9 & 23 & 11 & 7 & 9 & 27 \\
\hline & & $\begin{array}{l}\text { Településkate- } \\
\text { górián belüli } \\
\text { megoszlás }\end{array}$ & $39,1 \%$ & $21,7 \%$ & $39,1 \%$ & $100,0 \%$ & $40,7 \%$ & $25,9 \%$ & $33,3 \%$ & $100,0 \%$ \\
\hline \multirow{2}{*}{\multicolumn{2}{|c|}{ 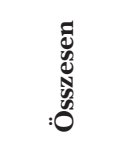 }} & Cégek száma & 28 & 18 & 19 & 65 & 40 & 16 & 19 & 75 \\
\hline & & $\begin{array}{l}\text { Településkate- } \\
\text { górián belüli } \\
\text { megoszlás }\end{array}$ & $43,1 \%$ & $27,7 \%$ & $29,2 \%$ & $100,0 \%$ & $53,3 \%$ & $21,3 \%$ & $25,3 \%$ & $100,0 \%$ \\
\hline
\end{tabular}

Forrás: Saját kutatás SPSS output alapján 
rosban tevékenykedô cégek esetében jelezte elôre a modell a csôdkockázatot.

A fôvárosi, megyei jogú városi és községi cégek esetében a túlélő kategóriába tartozó cégek aránya a vizsgált évek alatt (a tevékenység befejezését megelőzô 2. évre) csökkent. A modell továbbra is a megyei jogú városokban múködô cégek esetében jelezte előre a legnagyobb százalékban (66,7 százalék) a csôdkockázatot.

A vállalkozási tevékenység befejezését megelőzô évben a csôdelőrejelzési modell a különbözô településkategóriákba sorolt cégek településkategóriánként több mint 50 százalékában jelezte elôre a csôdveszélyt (3. táblázat). A fốvárosban múködô cégek esetében ez az érték 62,5 százalék, a városokban tevékenykedô vállalatoknál 59,1 százalék, megyei jogú városokban múködôknél 76,5 százalék, míg a községi cégek esetében
58,6 százalék. Az utolsó évben a csôdös vállalatok aránya tovább nôtt, s már a megyei jogú városokban múködô cégek és fốvárosi cégek több mint 77 százalékánál is jelezte a csôdveszélyt. Érdemes megfigyelni, hogy bár sok esetben a községek teljesítenek a leggyengébben, mégis a modell ezen kategóriában jelezte elôre a legkevésbé a csődkockázatot.

Összességében elmondható, hogy Altman csődelőrejelzési modellje nem jelezte előre valamennyi vizsgált cég esetében a csôdkockázatot (még a vállalkozási tevékenység befejezésének évében sem). A vizsgált években átlagosan a gazdasági társaságok 70-80 százalékánál (ha a szürkezónát is vizsgáljuk) jelezte elôre a modell a csôd bekövetkezését.

A 4. táblázat mutatja, hogy a különbözô területeken múködó társaságok és a csôdmodell alapján kiszámított értékek között kimutatható-e szignifikáns összefüggés.

2. táblázat: Az Altman-modell értékei a bázisév-3. és -2. évben

\begin{tabular}{|c|c|c|c|c|c|c|c|c|c|c|}
\hline & & & \multicolumn{3}{|c|}{$\begin{array}{c}\text { Altman-modell, bázisév } \\
-3 \text {. év }\end{array}$} & \multirow{2}{*}{$\begin{array}{l}\text { Össze- } \\
\text { sen }\end{array}$} & \multicolumn{3}{|c|}{$\begin{array}{c}\text { Altman-modell, bázisév } \\
-2 \text {. év }\end{array}$} & \multirow{2}{*}{$\begin{array}{c}\text { Össze- } \\
\text { sen }\end{array}$} \\
\hline & & & csôdös & $\begin{array}{l}\text { szürke- } \\
\text { zóna }\end{array}$ & túlélő & & csôdös & $\begin{array}{l}\text { szürke- } \\
\text { zóna }\end{array}$ & túlélő & \\
\hline \multirow{8}{*}{ 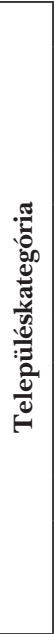 } & \multirow[b]{2}{*}{ 先 } & Cégek száma & 3 & 1 & 1 & 5 & 3 & 2 & 1 & 6 \\
\hline & & $\begin{array}{l}\text { Településkate- } \\
\text { górián belüli } \\
\text { megoszlás }\end{array}$ & $60,0 \%$ & $20,0 \%$ & $20,0 \%$ & $100,0 \%$ & $50,0 \%$ & $33,3 \%$ & $16,7 \%$ & $100,0 \%$ \\
\hline & \multirow[b]{2}{*}{ 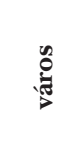 } & Cégek száma & 16 & 10 & 7 & 33 & 17 & 15 & 5 & 37 \\
\hline & & $\begin{array}{l}\text { Településkate- } \\
\text { górián belüli } \\
\text { megoszlás }\end{array}$ & $48,5 \%$ & $30,3 \%$ & $21,2 \%$ & $100,0 \%$ & $45,9 \%$ & $40,5 \%$ & $13,5 \%$ & $100,0 \%$ \\
\hline & \multirow{2}{*}{ 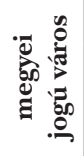 } & Cégek száma & 11 & 5 & 2 & 18 & 12 & 3 & 3 & 18 \\
\hline & & $\begin{array}{l}\text { Településkate- } \\
\text { górián belüli } \\
\text { megoszlás }\end{array}$ & $61,1 \%$ & $27,8 \%$ & $11,1 \%$ & $100,0 \%$ & $66,7 \%$ & $16,7 \%$ & $16,7 \%$ & $100,0 \%$ \\
\hline & \multirow[b]{2}{*}{ 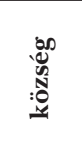 } & Cégek száma & 14 & 6 & 11 & 31 & 14 & 7 & 10 & 31 \\
\hline & & $\begin{array}{l}\text { Településkate- } \\
\text { górián belüli } \\
\text { megoszlás }\end{array}$ & $45,2 \%$ & $19,4 \%$ & $35,5 \%$ & $100,0 \%$ & $45,2 \%$ & $22,6 \%$ & $32,3 \%$ & $100,0 \%$ \\
\hline \multirow{2}{*}{\multicolumn{2}{|c|}{ 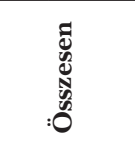 }} & Cégek száma & 44 & 22 & 21 & 87 & 46 & 27 & 19 & 92 \\
\hline & & $\begin{array}{l}\text { Településkate- } \\
\text { górián belüli } \\
\text { megoszlás }\end{array}$ & $50,6 \%$ & $25,3 \%$ & $24,1 \%$ & $100,0 \%$ & $50,0 \%$ & $29,3 \%$ & $20,7 \%$ & $100,0 \%$ \\
\hline
\end{tabular}

Forrás: Saját kutatás SPSS output alapján 


\section{Tudományos múhely}

3. táblázat: Az Altman-modell értékei a bázisév-1. évben és a bázisévben (a tevékenység befejezésének évében)

\begin{tabular}{|c|c|c|c|c|c|c|c|c|c|c|}
\hline & & & \multicolumn{3}{|c|}{$\begin{array}{c}\text { Altman-modell, bázisév } \\
-1 \text {. év }\end{array}$} & \multirow{2}{*}{$\begin{array}{l}\text { Össze- } \\
\text { sen }\end{array}$} & \multicolumn{3}{|c|}{$\begin{array}{l}\text { Altman-modell, } \\
\text { bázisévben }\end{array}$} & \multirow{2}{*}{$\begin{array}{c}\text { Össze- } \\
\text { sen }\end{array}$} \\
\hline & & & csôdös & $\begin{array}{l}\text { szürke- } \\
\text { zóna }\end{array}$ & túlélő & & csődös & $\begin{array}{l}\text { szürke- } \\
\text { zóna }\end{array}$ & túlélô & \\
\hline \multirow{8}{*}{ 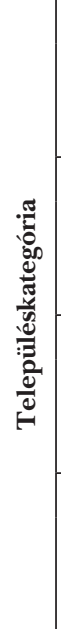 } & \multirow[b]{2}{*}{ 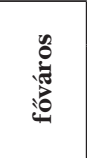 } & Cégek száma & 5 & 1 & 2 & 8 & 7 & 0 & 2 & 9 \\
\hline & & $\begin{array}{l}\text { Településkate- } \\
\text { górián belüli } \\
\text { megoszlás }\end{array}$ & $62,5 \%$ & $12,5 \%$ & $25,0 \%$ & $100,0 \%$ & $77,8 \%$ & $0,0 \%$ & $22,2 \%$ & $100,0 \%$ \\
\hline & \multirow[b]{2}{*}{ 突 } & Cégek száma & 26 & 8 & 10 & 44 & 25 & 5 & 11 & 41 \\
\hline & & $\begin{array}{l}\text { Településkate- } \\
\text { górián belüli } \\
\text { megoszlás }\end{array}$ & $59,1 \%$ & $18,2 \%$ & $22,7 \%$ & $100,0 \%$ & $61,0 \%$ & $12,2 \%$ & $26,8 \%$ & $100,0 \%$ \\
\hline & \multirow{2}{*}{ 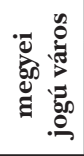 } & Cégek száma & 13 & 2 & 2 & 17 & 12 & 1 & 2 & 15 \\
\hline & & $\begin{array}{l}\text { Településkate- } \\
\text { górián belüli } \\
\text { megoszlás }\end{array}$ & $76,5 \%$ & $11,8 \%$ & $11,8 \%$ & $100,0 \%$ & $80,0 \%$ & $6,7 \%$ & $13,3 \%$ & $100,0 \%$ \\
\hline & \multirow[b]{2}{*}{ 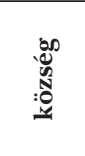 } & Cégek száma & 17 & 5 & 7 & 29 & 15 & 8 & 4 & 27 \\
\hline & & $\begin{array}{l}\text { Településkate- } \\
\text { górián belüli } \\
\text { megoszlás }\end{array}$ & $58,6 \%$ & $17,2 \%$ & $24,1 \%$ & $100,0 \%$ & $55,6 \%$ & $29,6 \%$ & $14,8 \%$ & $100,0 \%$ \\
\hline \multirow{2}{*}{\multicolumn{2}{|c|}{ 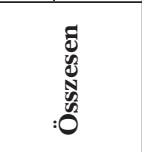 }} & Cégek száma & 61 & 16 & 21 & 98 & 59 & 14 & 19 & 92 \\
\hline & & $\begin{array}{l}\text { Településkate- } \\
\text { górián belüli } \\
\text { megoszlás }\end{array}$ & $62,2 \%$ & $16,3 \%$ & $21,4 \%$ & $100,0 \%$ & $64,1 \%$ & $15,2 \%$ & $20,7 \%$ & $100,0 \%$ \\
\hline
\end{tabular}

Forrás: Saját kutatás SPSS output alapján

4. táblázat: Chi²-próba (Altman-modell)

\begin{tabular}{l|c|c|c}
\hline & Value & df & $\begin{array}{c}\text { Asymp. Sig. } \\
\text { (2-sided) }\end{array}$ \\
\hline Pearson Chi-Square (bázisév) & $8,848^{\mathrm{a}}$ & 6 &, 182 \\
\hline
\end{tabular}

a. 5 cells $(41,7 \%)$ have expected count less than 5 . The minimum expected count is 1,37 .

\begin{tabular}{l|l|l|l}
\hline Pearson Chi-Square (bázis -1. év) & $2,003^{\mathrm{a}}$ & 6 &, 919 \\
\hline
\end{tabular}

a. 6 cells $(50,0 \%)$ have expected count less than 5 . The minimum expected count is 1,31 .

\begin{tabular}{l|c|c|c}
\hline Pearson Chi-Square (bázis -2. év) & $7,468^{\mathrm{a}}$ & 6 &, 280 \\
\hline
\end{tabular}

a. 4 cells $(33,3 \%)$ have expected count less than 5 . The minimum expected count is 1,24 .

\begin{tabular}{l|c|c|c}
\hline Pearson Chi-Square (bázis -3. év) & $4,621^{\text {a }}$ & 6 &, 593 \\
\hline
\end{tabular}

a. 5 cells $(41,7 \%)$ have expected count less than 5 . The minimum expected count is 1,21 .

\begin{tabular}{l|l|l|l}
\hline Pearson Chi-Square (bázis -4. év) & $6,851^{\text {a }}$ & 6 &, 335 \\
\hline
\end{tabular}

a. 5 cells $(41,7 \%)$ have expected count less than 5 . The minimum expected count is 1,49 .

\begin{tabular}{l|l|l|l|}
\hline Pearson Chi-Square (bázis -5. év) & $10,207^{\text {a }}$ & 6 &, 116 \\
\hline
\end{tabular}

a. 5 cells $(41,7 \%)$ have expected count less than 5 . The minimum expected count is 1,94 .

Forrás: Saját kutatás SPSS output alapján 
A statisztikai próba alapján egyik évben sem befolyásolta a vállalatok területi elhelyezkedése (azaz, hogy fôvárosban, megyei jogú városban, városban vagy községben múködô vállalat volt-e az önkormányzati társaság) a vállalatok csôdmodell szerint kiszámított értékeit, vagyis hogy csôdös vagy túlélô, illetve a szürkezónába került a vállalat.

$\mathrm{Az}$ 5-7. táblázat a Karas-modell szerinti értékeket szemlélteti. Míg Altman modellje ebben az évben a megyei jogú városokban múködô cégek 75 százalékánál jelzett csôdveszélyt, addig Karas modellje a vállalatok kevesebb mint 60 százalékánál jelzett problémát. Az összes céget megvizsgálva Karas modellje a társaságok 44,6 százalékát sorolta a túlélô kategóriába, ami optimistább (és egyben téves képet is mutat, tekintve, hogy a vállalatok öt év múlva befejezték vállalkozási tevékenységüket) Altman modelljénél (5. táblázat).
A bázisévet megelôzô 4. évben az előzô évhez képest visszaesést láthatunk, de így is kedvezóbben ítéli meg a modell a cégek helyzetét az Altman-modellnél. Tekintve, hogy mindkét modell ugyanazon mutatókon alapszik, nem meglepó, hogy ahogy Altman modelljénél, itt is a fôvárosi és a megyei jogú városi csôdös vállalatok aránya nôtt. A megyei jogú városokban múködó cégek közül csupán egy céget minôsít mindkét modell túlélốnek, a többi kategóriában azonban továbbra is Karas modellje fest optimistább képet.

A vállalkozási tevékenység befejezését megelôzô 2. és 3. évben a Karas-modell szerint a vállalatok 40,2 százalékánál nem állt fenn a csôd veszélye, Altman modelljénél ez az érték mindössze 20-24 százalék volt (6. táblázat). Míg Altman-modellje a megyei jogú városokban tevékenykedô gazdasági társaságok esetében jelezte előre nagymér-

5. táblázat: Karas és szerzôtársai modelljének értékei a bázisév-5. és -4. évben

\begin{tabular}{|c|c|c|c|c|c|c|c|c|c|c|}
\hline & \multicolumn{3}{|c|}{$\begin{array}{c}\text { Karas-modell, bázisév } \\
-5 . \text { év }\end{array}$} & \multirow{2}{*}{$\begin{array}{l}\text { Össze- } \\
\text { sen }\end{array}$} & \multicolumn{3}{|c|}{$\begin{array}{c}\text { Karas-modell, bázisév } \\
-4 . \text { év }\end{array}$} & \multirow{2}{*}{$\begin{array}{l}\text { Össze- } \\
\text { sen }\end{array}$} \\
\hline & & & csôdös & $\begin{array}{l}\text { szürke- } \\
\text { zóna }\end{array}$ & túlélő & & csôdös & $\begin{array}{l}\text { szürke- } \\
\text { zóna }\end{array}$ & túlélő & \\
\hline \multirow{8}{*}{ 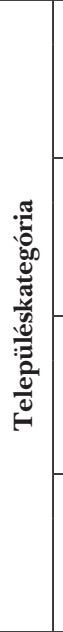 } & \multirow[b]{2}{*}{ 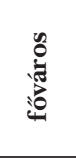 } & Cégek száma & 3 & 0 & 4 & 7 & 6 & 0 & 1 & 7 \\
\hline & & $\begin{array}{l}\text { Településkate- } \\
\text { górián belüli } \\
\text { megoszlás }\end{array}$ & $42,9 \%$ & $0,0 \%$ & $57,1 \%$ & $100,0 \%$ & $85,7 \%$ & $0,0 \%$ & $14,3 \%$ & $100,0 \%$ \\
\hline & \multirow[b]{2}{*}{ 总 } & Cégek száma & 7 & 6 & 10 & 23 & 10 & 7 & 10 & 27 \\
\hline & & $\begin{array}{l}\text { Településkate- } \\
\text { górián belüli } \\
\text { megoszlás }\end{array}$ & $30,4 \%$ & $26,1 \%$ & $43,5 \%$ & $100,0 \%$ & $37,0 \%$ & $25,9 \%$ & $37,0 \%$ & $100,0 \%$ \\
\hline & \multirow{2}{*}{ 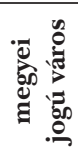 } & Cégek száma & 7 & 1 & 4 & 12 & 9 & 4 & 1 & 14 \\
\hline & & $\begin{array}{l}\text { Településkate- } \\
\text { górián belüli } \\
\text { megoszlás }\end{array}$ & $58,3 \%$ & $8,3 \%$ & $33,3 \%$ & $100,0 \%$ & $64,3 \%$ & $28,6 \%$ & $7,1 \%$ & $100,0 \%$ \\
\hline & \multirow[b]{2}{*}{ 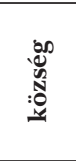 } & Cégek száma & 7 & 5 & 11 & 23 & 7 & 6 & 14 & 27 \\
\hline & & $\begin{array}{l}\text { Településkate- } \\
\text { górián belüli } \\
\text { megoszlás }\end{array}$ & $30,4 \%$ & $21,7 \%$ & $47,8 \%$ & $100,0 \%$ & $25,9 \%$ & $22,2 \%$ & $51,9 \%$ & $100,0 \%$ \\
\hline \multirow{2}{*}{\multicolumn{2}{|c|}{ 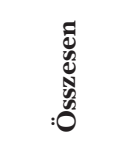 }} & Cégek száma & 24 & 12 & 29 & 65 & 32 & 17 & 26 & 75 \\
\hline & & $\begin{array}{l}\text { Településkate- } \\
\text { górián belüli } \\
\text { megoszlás }\end{array}$ & $36,9 \%$ & $18,5 \%$ & $44,6 \%$ & $100,0 \%$ & $42,7 \%$ & $22,7 \%$ & $34,7 \%$ & $100,0 \%$ \\
\hline
\end{tabular}

Forrás: Saját kutatás SPSS output alapján 


\section{Tudományos múhely}

6. táblázat: Karas és szerzôtársai modelljének értékei a bázisév-3. és-2. évben

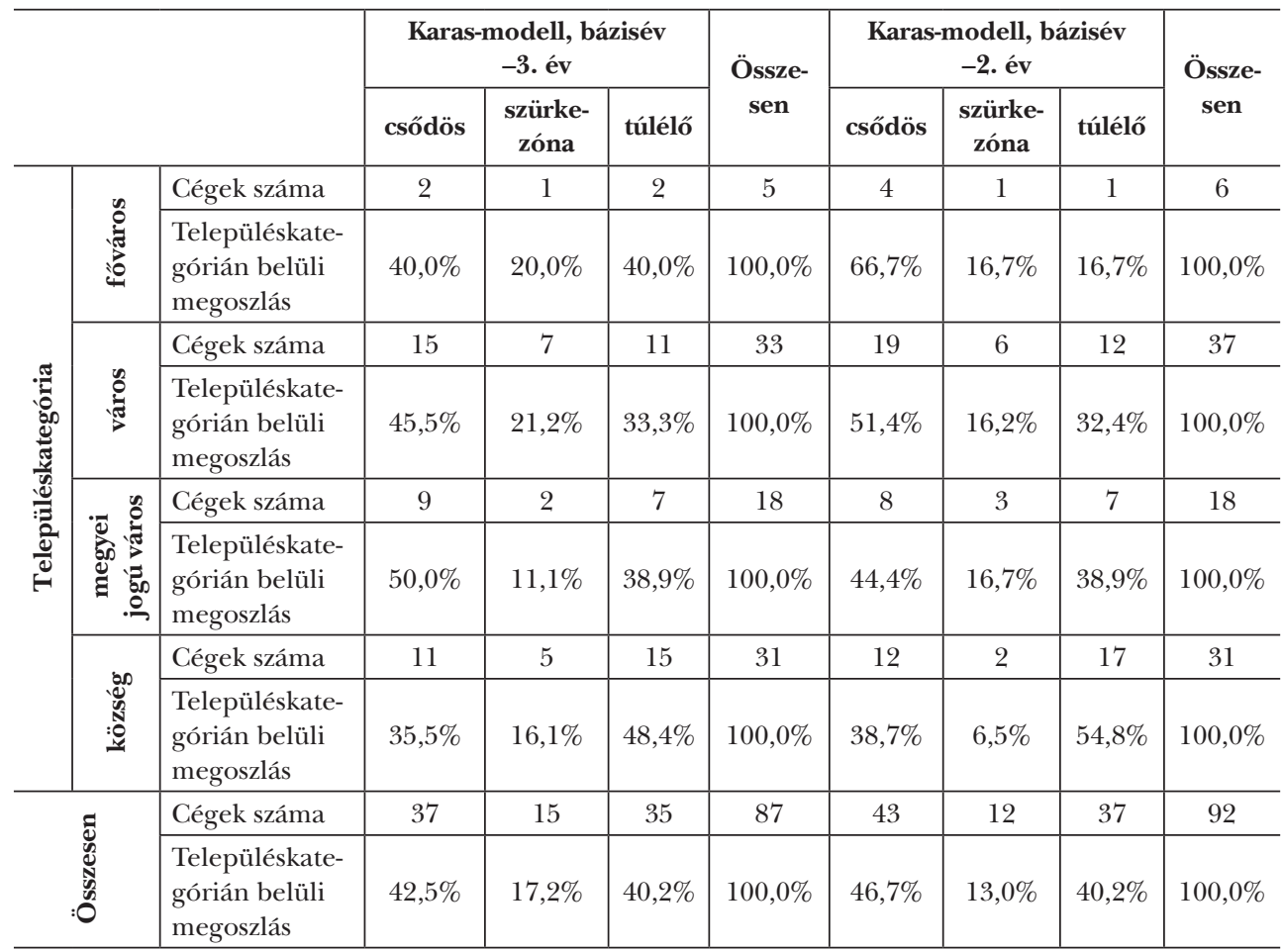

Forrás: Saját kutatás SPSS output alapján

tékben a csôdkockázatot, addig Karas modellje a községekben múködó cégek esetében sorolt több céget a csốdös kategóriába (amelyeket Altman a szürkezónába).

Nagymértékú az eltérés a városi és a megyei jogú városi társaságok esetében, míg Altman szerint mindössze 22,7 és 11,8 százalékuknak fenntartható a pénzügyi helyzete, addig a Karas-modell szerint ezek az értékek rendre 34,1 és 29,4 százalék, amely több mint 12 százalékos eltérést mutat (7. táblázat).

Az utolsó évben mind Altman, mind pedig Karas modellje a vállalkozások több mint 60 százalékánál jelezte a csôdveszélyt. Karas modellje hat vállalkozás esetében kedvezóbbnek ítélte a vállalatok helyzetét, melyeket Altman a szürkezónába sorolt. Összességében elmondható, hogy Karas modellje valamennyi évben kedvezóbben ítélte meg a vállalatok hosszú távú fennmaradását, s mindkét modell a tevékenység megszüntetésének évében a cégek több mint 20 százalékánál nem jelezte a csốdkockázatot.

A statisztikai próbát elvégezve (8. táblázat), a modell értékei és a területi elhelyezkedés között szignifikáns összefüggés mutatható ki a vállalkozási tevékenység befejezését megelőzô 4. évben. A településkategória meghatározta a csôdmodell alapján számított vállalkozások értékeit.

A 9-11. táblázat a brazil vállalatokra fejlesztett modell értékeit mutatja.

A brazil vállalkozásokra számított modell a szürkezónát elhagyja, csak a csôdös és túlélő kategóriát használja. A modell ellentétes képet mutat az elóbbiekben bemutatott két modellel szemben a vállalati tevékenység beszüntetését megelôzó 5. évben (9. táblázat). A modell szerint a vizsgált vállalatok 64,6 százalékánál nem áll fenn a csôd veszélye. 


\section{Tudományos múhely}

7. táblázat: Karas és szerzôtársai modelljének értékei a bázisév-1. és a bázisévben

\begin{tabular}{|c|c|c|c|c|c|c|c|c|c|c|}
\hline & \multicolumn{3}{|c|}{$\begin{array}{c}\text { Karas-modell, bázisév } \\
-1 \text {. év }\end{array}$} & \multirow{2}{*}{$\begin{array}{l}\text { Össze- } \\
\text { sen }\end{array}$} & \multicolumn{3}{|c|}{$\begin{array}{c}\text { Karas-modell, } \\
\text { bázisévben }\end{array}$} & \multirow{2}{*}{$\begin{array}{l}\text { Össze- } \\
\text { sen }\end{array}$} \\
\hline & & & csôdös & $\begin{array}{l}\text { szürke- } \\
\text { zóna }\end{array}$ & túlélő & & csôdös & $\begin{array}{l}\text { szürke- } \\
\text { zóna }\end{array}$ & túlélő & \\
\hline \multirow{8}{*}{ 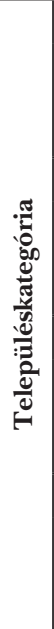 } & \multirow[b]{2}{*}{ 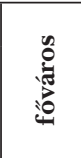 } & Cégek száma & 4 & 1 & 3 & 8 & 5 & 0 & 4 & 9 \\
\hline & & $\begin{array}{l}\text { Településkate- } \\
\text { górián belüli } \\
\text { megoszlás }\end{array}$ & $50,0 \%$ & $12,5 \%$ & $37,5 \%$ & $100,0 \%$ & $55,6 \%$ & $0,0 \%$ & $44,4 \%$ & $100,0 \%$ \\
\hline & \multirow[b]{2}{*}{ 照 } & Cégek száma & 23 & 6 & 15 & 44 & 24 & 4 & 13 & 41 \\
\hline & & $\begin{array}{l}\text { Településkate- } \\
\text { górián belüli } \\
\text { megoszlás }\end{array}$ & $52,3 \%$ & $13,6 \%$ & $34,1 \%$ & $100,0 \%$ & $58,5 \%$ & $9,8 \%$ & $31,7 \%$ & $100,0 \%$ \\
\hline & \multirow{2}{*}{ 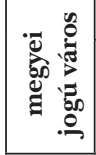 } & Cégek száma & 10 & 2 & 5 & 17 & 11 & 1 & 3 & 15 \\
\hline & & $\begin{array}{l}\text { Településkate- } \\
\text { górián belüli } \\
\text { megoszlás }\end{array}$ & $58,8 \%$ & $11,8 \%$ & $29,4 \%$ & $100,0 \%$ & $73,3 \%$ & $6,7 \%$ & $20,0 \%$ & $100,0 \%$ \\
\hline & \multirow[b]{2}{*}{ 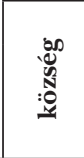 } & Cégek száma & 19 & 2 & 8 & 29 & 18 & 3 & 6 & 27 \\
\hline & & $\begin{array}{l}\text { Településkate- } \\
\text { górián belüli } \\
\text { megoszlás }\end{array}$ & $65,5 \%$ & $6,9 \%$ & $27,6 \%$ & $100,0 \%$ & $66,7 \%$ & $11,1 \%$ & $22,2 \%$ & $100,0 \%$ \\
\hline \multirow{2}{*}{\multicolumn{2}{|c|}{ 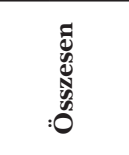 }} & Cégek száma & 56 & 11 & 31 & 98 & 58 & 8 & 26 & 92 \\
\hline & & $\begin{array}{l}\text { Településkate- } \\
\text { górián belüli } \\
\text { megoszlás }\end{array}$ & $57,1 \%$ & $11,2 \%$ & $31,6 \%$ & $100,0 \%$ & $63,0 \%$ & $8,7 \%$ & $28,3 \%$ & $100,0 \%$ \\
\hline
\end{tabular}

Forrás: Saját kutatás SPSS output alapján

8. táblázat: Chi²-próba (Karas és szerzótársai modellje)

\begin{tabular}{l|c|c|c}
\hline & Value & df & $\begin{array}{c}\text { Asymp. Sig. } \\
\text { (2-sided) }\end{array}$ \\
\hline Pearson Chi-Square (bázisév) & $3,325^{\mathrm{a}}$ & 6 &, 767 \\
\hline
\end{tabular}

a. 6 cells $(50,0 \%)$ have expected count less than 5 . The minimum expected count is , 78 .

\begin{tabular}{l|c|c|c}
\hline Pearson Chi-Square (bázis -1. év ) & $1,694^{\mathrm{a}}$ & 6 &, 946 \\
\hline
\end{tabular}

a. 6 cells $(50,0 \%)$ have expected count less than 5 . The minimum expected count is, 90 .

\begin{tabular}{l|c|c|c}
\hline Pearson Chi-Square (bázis -2. év ) & $5,727^{\text {a }}$ & 6 &, 454 \\
\hline
\end{tabular}

a. 6 cells $(50,0 \%)$ have expected count less than 5 . The minimum expected count is, 78 .

\begin{tabular}{l|c|c|c}
\hline Pearson Chi-Square (bázis -3. év ) & $2,321^{\text {a }}$ & 6 &, 888 \\
\hline
\end{tabular}

a. 4 cells $(33,3 \%)$ have expected count less than 5 . The minimum expected count is, 86 .

\begin{tabular}{l|c|c|c}
\hline Pearson Chi-Square (bázis -4. év ) & $14,721^{\mathrm{a}}$ & 6 &, 023 \\
\hline
\end{tabular}

a. 5 cells $(41,7 \%)$ have expected count less than 5 . The minimum expected count is 1,59 .

\begin{tabular}{l|c|c|c}
\hline Pearson Chi-Square (bázis -5 . év ) & $5,547^{\text {a }}$ & 6 &, 476 \\
\hline
\end{tabular}

a. 7 cells $(58,3 \%)$ have expected count less than 5 . The minimum expected count is 1,29 .

Forrás: Saját kutatás SPSS output alapján 


\section{Tudományos múhely}

9. táblázat: A brazil modell értékei a bázisév-5. és -4. évben

\begin{tabular}{|c|c|c|c|c|c|c|c|c|}
\hline & & & \multicolumn{2}{|c|}{$\begin{array}{l}\text { Brazil-modell, } \\
\text { bázisév -5. év }\end{array}$} & \multirow[t]{2}{*}{ Összesen } & \multicolumn{2}{|c|}{$\begin{array}{l}\text { Brazil-modell, } \\
\text { bázisév -4. év }\end{array}$} & \multirow[t]{2}{*}{ Összesen } \\
\hline & & & csôdös & túlélő & & csôdös & túlélő & \\
\hline \multirow{8}{*}{ 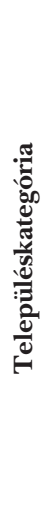 } & \multirow{2}{*}{ 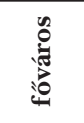 } & Cégek száma & 3 & 4 & 7 & 6 & 1 & 7 \\
\hline & & $\begin{array}{l}\text { Településkategórián } \\
\text { belüli megoszlás }\end{array}$ & $42,9 \%$ & $57,1 \%$ & $100,0 \%$ & $85,7 \%$ & $14,3 \%$ & $100,0 \%$ \\
\hline & \multirow{2}{*}{ 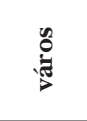 } & Cégek száma & 7 & 16 & 23 & 11 & 16 & 27 \\
\hline & & $\begin{array}{l}\text { Településkategórián } \\
\text { belüli megoszlás }\end{array}$ & $30,4 \%$ & $69,6 \%$ & $100,0 \%$ & $40,7 \%$ & $59,3 \%$ & $100,0 \%$ \\
\hline & \multirow{2}{*}{ 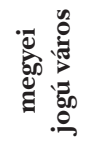 } & Cégek száma & 7 & 5 & 12 & 8 & 6 & 14 \\
\hline & & $\begin{array}{l}\text { Településkategórián } \\
\text { belüli megoszlás }\end{array}$ & $58,3 \%$ & $41,7 \%$ & $100,0 \%$ & $57,1 \%$ & $42,9 \%$ & $100,0 \%$ \\
\hline & \multirow{2}{*}{ 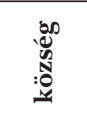 } & Cégek száma & 6 & 17 & 23 & 9 & 18 & 27 \\
\hline & & $\begin{array}{l}\text { Településkategórián } \\
\text { belüli megoszlás }\end{array}$ & $26,1 \%$ & $73,9 \%$ & $100,0 \%$ & $33,3 \%$ & $66,7 \%$ & $100,0 \%$ \\
\hline \multirow{2}{*}{\multicolumn{2}{|c|}{ 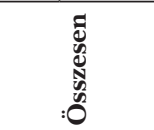 }} & Cégek száma & 23 & 42 & 65 & 34 & 41 & 75 \\
\hline & & $\begin{array}{l}\text { Településkategórián } \\
\text { belüli megoszlás }\end{array}$ & $35,4 \%$ & $64,6 \%$ & $100,0 \%$ & $45,3 \%$ & $54,7 \%$ & $100,0 \%$ \\
\hline
\end{tabular}

Forrás: Saját kutatás SPSS output alapján

10. táblázat: A brazil modell értékei a bázisév-3. és-2. évben

\begin{tabular}{|c|c|c|c|c|c|c|c|c|}
\hline & & & \multicolumn{2}{|c|}{$\begin{array}{l}\text { Brazil modell, } \\
\text { bázisév-3. év }\end{array}$} & \multirow[t]{2}{*}{ Összesen } & \multicolumn{2}{|c|}{$\begin{array}{l}\text { Brazil modell, } \\
\text { bázisév-2. év }\end{array}$} & \multirow[t]{2}{*}{ Összesen } \\
\hline & & & csôdös & túlélő & & csôdös & túlélő & \\
\hline \multirow{8}{*}{ 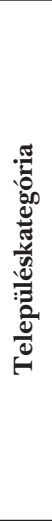 } & \multirow{2}{*}{ 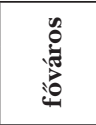 } & Cégek száma & 2 & 3 & 5 & 4 & 2 & 6 \\
\hline & & $\begin{array}{l}\text { Településkategórián } \\
\text { belüli megoszlás }\end{array}$ & $40,0 \%$ & $60,0 \%$ & $100,0 \%$ & $66,7 \%$ & $33,3 \%$ & $100,0 \%$ \\
\hline & \multirow{2}{*}{ 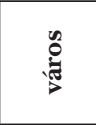 } & Cégek száma & 14 & 19 & 33 & 16 & 21 & 37 \\
\hline & & $\begin{array}{l}\text { Településkategórián } \\
\text { belüli megoszlás }\end{array}$ & $42,4 \%$ & $57,6 \%$ & $100,0 \%$ & $43,2 \%$ & $56,8 \%$ & $100,0 \%$ \\
\hline & \multirow{2}{*}{ 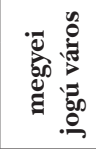 } & Cégek száma & 9 & 9 & 18 & 8 & 10 & 18 \\
\hline & & $\begin{array}{l}\text { Településkategórián } \\
\text { belüli megoszlás }\end{array}$ & $50,0 \%$ & $50,0 \%$ & $100,0 \%$ & $44,4 \%$ & $55,6 \%$ & $100,0 \%$ \\
\hline & \multirow{2}{*}{ 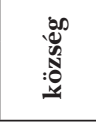 } & Cégek száma & 10 & 21 & 31 & 12 & 19 & 31 \\
\hline & & $\begin{array}{l}\text { Településkategórián } \\
\text { belüli megoszlás }\end{array}$ & $32,3 \%$ & $67,7 \%$ & $100,0 \%$ & $38,7 \%$ & $61,3 \%$ & $100,0 \%$ \\
\hline \multirow{2}{*}{\multicolumn{2}{|c|}{ 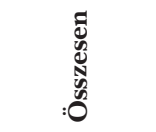 }} & Cégek száma & 35 & 52 & 87 & 40 & 52 & 92 \\
\hline & & $\begin{array}{l}\text { Településkategórián } \\
\text { belüli megoszlás }\end{array}$ & $40,2 \%$ & $59,8 \%$ & $100,0 \%$ & $43,5 \%$ & $56,5 \%$ & $100,0 \%$ \\
\hline
\end{tabular}

Forrás: Saját kutatás SPSS output alapján 


\begin{tabular}{|c|c|c|c|c|c|c|c|c|}
\hline & & & \multicolumn{2}{|c|}{$\begin{array}{l}\text { Brazil modell, } \\
\text { bázisév -1. év }\end{array}$} & \multirow[t]{2}{*}{ Összesen } & \multicolumn{2}{|c|}{$\begin{array}{l}\text { Brazil modell, } \\
\text { bázisévben }\end{array}$} & \multirow[t]{2}{*}{ Összesen } \\
\hline & & & csódös & túléló & & csődös & túléló & \\
\hline \multirow{8}{*}{ 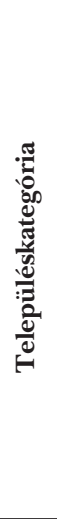 } & \multirow{2}{*}{ 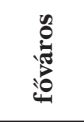 } & Cégek száma & 4 & 4 & 8 & 5 & 4 & 9 \\
\hline & & $\begin{array}{l}\text { Településkategórián } \\
\text { belüli megoszlás }\end{array}$ & $50,0 \%$ & $50,0 \%$ & $100,0 \%$ & $55,6 \%$ & $44,4 \%$ & $100,0 \%$ \\
\hline & \multirow{2}{*}{ : } & Cégek száma & 20 & 24 & 44 & 23 & 18 & 41 \\
\hline & & $\begin{array}{l}\text { Településkategórián } \\
\text { belüli megoszlás }\end{array}$ & $45,5 \%$ & $54,5 \%$ & $100,0 \%$ & $56,1 \%$ & $43,9 \%$ & $100,0 \%$ \\
\hline & \multirow{2}{*}{ 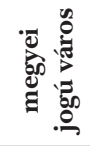 } & Cégek száma & 10 & 7 & 17 & 10 & 5 & 15 \\
\hline & & $\begin{array}{l}\text { Településkategórián } \\
\text { belüli megoszlás }\end{array}$ & $58,8 \%$ & $41,2 \%$ & $100,0 \%$ & $66,7 \%$ & $33,3 \%$ & $100,0 \%$ \\
\hline & \multirow{2}{*}{ 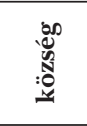 } & Cégek száma & 15 & 14 & 29 & 19 & 8 & 27 \\
\hline & & $\begin{array}{l}\text { Településkategórián } \\
\text { belüli megoszlás }\end{array}$ & $51,7 \%$ & $48,3 \%$ & $100,0 \%$ & $70,4 \%$ & $29,6 \%$ & $100,0 \%$ \\
\hline \multirow{2}{*}{\multicolumn{2}{|c|}{ 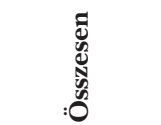 }} & Cégek száma & 49 & 49 & 98 & 57 & 35 & 92 \\
\hline & & $\begin{array}{l}\text { Településkategórián } \\
\text { belüli megoszlás }\end{array}$ & $50,0 \%$ & $50,0 \%$ & $100,0 \%$ & $62,0 \%$ & $38,0 \%$ & $100,0 \%$ \\
\hline
\end{tabular}

Forrás: Saját kutatás SPSS output alapján

A 10. táblázatból jól látható, hogy ezen két vizsgált idôszakban több mint 20 százalékos az eltérés a túlélố cégek aránya között a Karas-modellhez képest, Altman modelljéhez képest ez az érték jóval magasabb, 35 százalék. A tevékenység befejezésének évét megelózô 3. évben a vállalatok 59,8 százalékát, a tevékenység befejezését megelôzô 2. évben pedig a cégek 56,5 százalékát ítélte a modell múködóképesnek.

A brazil vállalatokra megalkotott modell szerint az utolsó elôtti évben a vállalatok mindössze 50 százalékánál állt fenn a csôd veszélye (11. táblázat), az Altman-modell esetében ez az érték 62,2 százalék volt, Karas modellje esetében 57,1 százalék, ugyanakkor az is elmondható, hogy a szürkezónába a két modell rendre a cégek 16,3 és 11,2 százalékát sorolta, amely nem egy stabil pénzügyi helyzetet jelez. Azaz míg Altman modellje alig a vállalkozások 21 százalékát minôsítette túlélónek, addig a brazil modell a cégek 50 százalékát, amely eltérés igen nagy fokúnak mondható.
A vállalkozási tevékenységet befejezô évben a modell értéke már hasonló képet mutat Altman modelljével, mindkét modell szerint a társaságok több mint 60 százaléka (62-64 százalék) csốdveszélyes állapotban volt (Karas modellje némileg elmaradt, az érték ott 57 százalék volt).

Összességében elmondható, hogy a brazil modell értékelte a legkedvezóbbnek a vállalatok helyzetét, hozzátéve, hogy igen helytelenül, hiszen valamennyi vizsgált cég megszüntette a tevékenységét. Elmondható ugyanakkor, hogy Altman modellje ítélte nagyobb számban a cégeket csôdveszélyesnek, és jelezte elôre helyesen a csôd kockázatát.

A statisztikai próba nem mutatott szignifikáns összefüggést a területi elhelyezkedés és a modell értékei között egyik évben sem (12. táblázat).

Mivel a csôdelôrejelzési modellek mindössze a cégek 60 százalékánál jelezte elôre a csôdkockázatot, érdemesnek tartottam megvizsgálni a tôkeerôsség (azaz, hogy a 
12. táblázat: Chi²-próba (brazil modell)

\begin{tabular}{l|c|c|c}
\hline & Value & df & $\begin{array}{c}\text { Asymp. Sig. } \\
\text { (2-sided) }\end{array}$ \\
\hline Pearson Chi-Square & $4,051^{\mathrm{a}}$ & 3 &, 256 \\
\hline
\end{tabular}

a. 3 cells $(37,5 \%)$ have expected count less than 5 . The minimum expected count is 2,48 .

\begin{tabular}{l|c|c|c}
\hline Pearson Chi-Square (bázisév) & $1,706^{\mathrm{a}}$ & 3 &, 636 \\
\hline
\end{tabular}

a. 1 cells $(12,5 \%)$ have expected count less than 5 . The minimum expected count is 3,42 .

\begin{tabular}{l|c|c|c}
\hline Pearson Chi-Square (bázis -1. év ) & $928^{\text {a }}$ & 3 &, 819 \\
\hline
\end{tabular}

a. 2 cells $(25,0 \%)$ have expected count less than 5 . The minimum expected count is 4,00 .

\begin{tabular}{l|c|c|c}
\hline Pearson Chi-Square (bázis -2. év ) & $1,607^{\mathrm{a}}$ & 3 &, 658 \\
\hline
\end{tabular}

a. 2 cells $(25,0 \%)$ have expected count less than 5 . The minimum expected count is 2,61 .

\begin{tabular}{l|c|c|c|}
\hline Pearson Chi-Square (bázis -3. év ) & $1,600^{\mathrm{a}}$ & 3 &, 659
\end{tabular}

a. 2 cells $(25,0 \%)$ have expected count less than 5 . The minimum expected count is 2,01 .

\begin{tabular}{l|c|c|c}
\hline Pearson Chi-Square (bázis -4. év ) & $7,192^{\text {a }}$ & 3 &, 066 \\
\hline
\end{tabular}

a. 2 cells $(25,0 \%)$ have expected count less than 5 . The minimum expected count is 3,17 .

\begin{tabular}{l|c|c|c}
\hline Pearson Chi-Square (bázis -5. év ) & $4,051^{\mathrm{a}}$ & 3 &, 256 \\
\hline
\end{tabular}

a. 3 cells $(37,5 \%)$ have expected count less than 5 . The minimum expected count is 2,48 .

Forrás: Saját kutatás SPSS output alapján

vállalatok milyen mértékben adósodtak el, vagy az évek során mekkora mértékben halmoztak fel adósságot: negatív saját tôke, lásd 13. táblázat), valamint a likviditás alakulását (1. ábra).

A 13. táblázat a tôkeerôsségi mutatók alakulását mutatja. A cégek tôkeerôsségi mutatóit különbözố csoportokba kategorizáltam. Nagyon gyengének minősítettem azt a mutatót, melynek értéke 30 százalék alatt volt, gyenge tôkeerôsségú az a vállalat, ahol a mutató értéke 31 és 50 százalék közötti. Az 51 és 70 százalék közötti érték elfogadható a mutató esetében, és stabil tôkehelyzetú azon vállalat, melynek mutatója 71 százalék feletti. A bázisévet megelőzó 4. és 5. évben a társaságok 41,2-42,7 százalékának volt elfogadható a tôkeerôsségi mutatója, illetve stabil a tôkehelyzete. A következô két évben ez az arány visszaesett 34,2-34,4 százalékra, s jellemzôen a negatív saját tőkével rendelkezô cégek, valamint a nagyon gyenge saját tôkearánnyal rendelkezó cégek száma nôtt. A vállalkozási tevékenység utolsó évében, illetve az azt megelôzố év- ben a vállalatok 36,4 és 36,7 százalékának volt kedvezố a tôkeszerkezete. Az utolsó évben a tôkeerôsségi mutatók értékei a brazil modellt támasztják alá, a modell szerint a túlélő cégek aránya 38 százalék. A tôkeerôsség vizsgálata után nézzük, hogyan alakult a vállalkozások likviditási helyzete (1. ábra).

A tôkeerôsség csoportosítása után a likviditási mutatókat is kategóriákba soroltam. Gyenge likviditású azon vállalkozás, melynél a mutató értéke 1 alatt volt, elfogadható, ahol a mutató értéke 1 és 1,3 között, erôs likviditású az, ahol az érték 1,3 és 1,8 között, kimagasló pedig az 1,8 feletti. Túlzott likviditásúnak ítéltem meg azon vállalkozásokat, ahol a forgóeszközök értéke irreálisan nagynak bizonyult a rövid lejáratú kötelezettségekhez viszonyítva, amely azért is problémás, mert a vállalatnak túl sok a lekötetlen pénzeszköze, és a jövedelmezóség romlását eredményezi. A túlzott likviditású cégek aránya az összes vizsgált vállalkozáson belül nôtt az évek során. Bár a gyenge likviditású cégek arányában némi visszaesést tapasztalhatunk az évek során, azonban 


\section{Tudományos múhely}

\section{3. táblázat: A gazdasági társaságok saját tôkearányának alakulása}

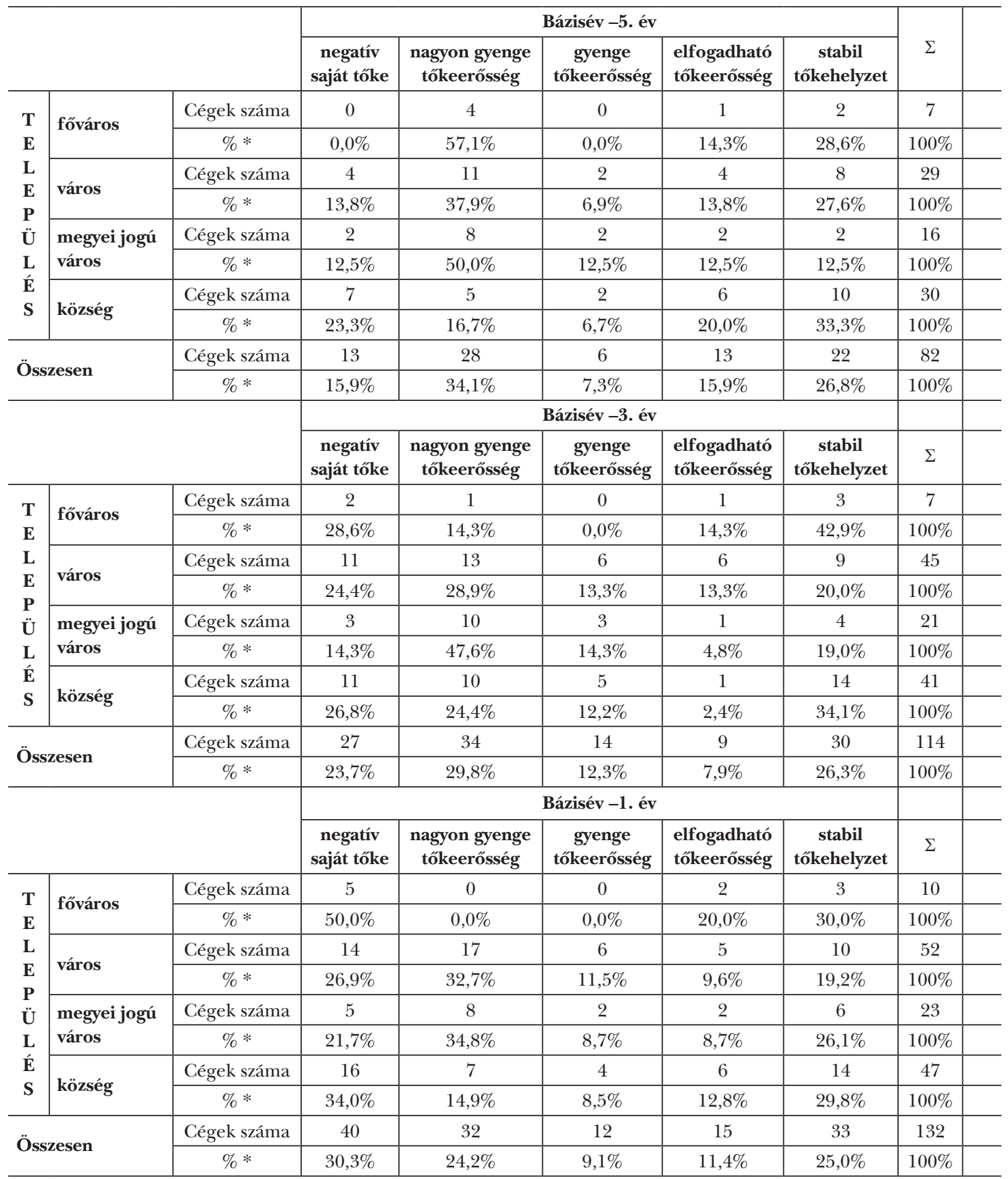

Megjegyzés: *településkategórián belül

Forrás: Saját kutatás SPSS output alapján 


\section{Tudományos múhely}

\begin{tabular}{|c|c|c|c|c|c|c|c|c|}
\hline & & & \multicolumn{5}{|c|}{ Bázisév -4. év } & \multirow[b]{2}{*}{$\Sigma$} \\
\hline & & & $\begin{array}{c}\text { negatív } \\
\text { saját tóke }\end{array}$ & $\begin{array}{c}\text { nagyon gyenge } \\
\text { tókeerósség }\end{array}$ & $\begin{array}{c}\text { gyenge } \\
\text { tókeerôsség }\end{array}$ & $\begin{array}{l}\text { elfogadható } \\
\text { tókeerósség }\end{array}$ & $\begin{array}{c}\text { stabil } \\
\text { tókehelyzet }\end{array}$ & \\
\hline \multirow{2}{*}{$\begin{array}{l}\mathbf{T} \\
\mathbf{E}\end{array}$} & \multirow{2}{*}{ fôváros } & Cégek száma & 3 & 1 & 0 & 2 & 1 & 7 \\
\hline & & $\% *$ & $42,9 \%$ & $14,3 \%$ & $0,0 \%$ & $28,6 \%$ & $14,3 \%$ & $100 \%$ \\
\hline \multirow{2}{*}{$\begin{array}{l}\mathbf{L} \\
\mathbf{E} \\
\mathbf{P}\end{array}$} & \multirow{2}{*}{ város } & Cégek száma & 7 & 12 & 2 & 7 & 7 & 35 \\
\hline & & $\% *$ & $20,0 \%$ & $34,3 \%$ & $5,7 \%$ & $20,0 \%$ & $20,0 \%$ & $100 \%$ \\
\hline$\ddot{\mathbf{U}}$ & \multirow{2}{*}{$\begin{array}{l}\text { megyei jogú } \\
\text { város }\end{array}$} & Cégek száma & 2 & 8 & 4 & 0 & 5 & 19 \\
\hline $\mathbf{L}$ & & $\% *$ & $10,5 \%$ & $42,1 \%$ & $21,1 \%$ & $0,0 \%$ & $26,3 \%$ & $100 \%$ \\
\hline $\begin{array}{l}\mathbf{E} \\
\mathbf{S}\end{array}$ & \multirow{2}{*}{ község } & Cégek száma & 9 & 7 & 2 & 7 & 11 & 36 \\
\hline & & $\% *$ & $25,0 \%$ & $19,4 \%$ & $5,6 \%$ & $19,4 \%$ & $30,6 \%$ & $100 \%$ \\
\hline \multirow{2}{*}{\multicolumn{2}{|c|}{ Összesen }} & Cégek száma & 21 & 28 & 8 & 16 & 24 & 97 \\
\hline & & $\% *$ & $21,6 \%$ & $28,9 \%$ & $8,2 \%$ & $16,5 \%$ & $24,7 \%$ & $100 \%$ \\
\hline & & & \multicolumn{5}{|c|}{ Bázisév-2. év } & \\
\hline & & & $\begin{array}{c}\text { negatív } \\
\text { saját tóke }\end{array}$ & $\begin{array}{c}\text { nagyon gyenge } \\
\text { tőkeerôsség }\end{array}$ & $\begin{array}{c}\text { gyenge } \\
\text { tókeerôsség }\end{array}$ & $\begin{array}{l}\text { elfogadható } \\
\text { tókeerôsség }\end{array}$ & $\begin{array}{c}\text { stabil } \\
\text { tôkehelyzet }\end{array}$ & $\Sigma$ \\
\hline \multirow{8}{*}{$\begin{array}{c}\mathbf{T} \\
\mathbf{E} \\
\mathbf{L} \\
\mathbf{E} \\
\mathbf{P} \\
\ddot{\mathbf{U}} \\
\mathbf{L} \\
\mathbf{E} \\
\mathbf{S}\end{array}$} & \multirow{2}{*}{ fôváros } & Cégek száma & 4 & 0 & 1 & 2 & 1 & 8 \\
\hline & & $\% *$ & $50,0 \%$ & $0,0 \%$ & $12,5 \%$ & $25,0 \%$ & $12,5 \%$ & $100 \%$ \\
\hline & \multirow{2}{*}{ város } & Cégek száma & 10 & 18 & 4 & 6 & 9 & 47 \\
\hline & & $\% *$ & $21,3 \%$ & $38,3 \%$ & $8,5 \%$ & $12,8 \%$ & $19,1 \%$ & $100 \%$ \\
\hline & \multirow{2}{*}{$\begin{array}{l}\text { megyei jogú } \\
\text { város }\end{array}$} & Cégek száma & 4 & 9 & 3 & 4 & 2 & 22 \\
\hline & & $\% *$ & $18,2 \%$ & $40,9 \%$ & $13,6 \%$ & $18,2 \%$ & $9,1 \%$ & $100 \%$ \\
\hline & \multirow{2}{*}{ község } & Cégek száma & 12 & 12 & 3 & 4 & 14 & 45 \\
\hline & & $\% *$ & $26,7 \%$ & $26,7 \%$ & $6,7 \%$ & $8,9 \%$ & $31,1 \%$ & $100 \%$ \\
\hline \multirow{2}{*}{\multicolumn{2}{|c|}{ Összesen }} & Cégek száma & 30 & 39 & 11 & 16 & 26 & 122 \\
\hline & & $\% *$ & $24,6 \%$ & $32,0 \%$ & $9,0 \%$ & $13,1 \%$ & $21,3 \%$ & $100 \%$ \\
\hline & & & \multicolumn{5}{|c|}{ Bázisév } & \\
\hline & & & $\begin{array}{c}\text { negatív } \\
\text { saját tóke }\end{array}$ & $\begin{array}{c}\text { nagyon gyenge } \\
\text { tókeerôsség }\end{array}$ & $\begin{array}{c}\text { gyenge } \\
\text { tôkeerôsség }\end{array}$ & $\begin{array}{l}\text { elfogadható } \\
\text { tókeerôsség }\end{array}$ & $\begin{array}{c}\text { stabil } \\
\text { tókehelyzet }\end{array}$ & $\Sigma$ \\
\hline \multirow{2}{*}{\multicolumn{2}{|c|}{\begin{tabular}{l|l}
$\mathbf{T}$ & fóváros \\
$\mathbf{E}$ &
\end{tabular}}} & Cégek száma & 5 & 0 & 1 & 2 & 2 & 10 \\
\hline & & $\% *$ & $50,0 \%$ & $0,0 \%$ & $10,0 \%$ & $20,0 \%$ & $20,0 \%$ & $100 \%$ \\
\hline \multirow{6}{*}{$\begin{array}{c}\mathbf{L} \\
\mathbf{E} \\
\mathbf{P} \\
\ddot{\mathbf{U}} \\
\mathbf{L} \\
\hat{\mathbf{E}} \\
\mathbf{S}\end{array}$} & \multirow{2}{*}{ város } & Cégek száma & 18 & 10 & 6 & 2 & 17 & 53 \\
\hline & & $\% *$ & $34,0 \%$ & $18,9 \%$ & $11,3 \%$ & $3,8 \%$ & $32,1 \%$ & $100 \%$ \\
\hline & \multirow{2}{*}{$\begin{array}{l}\text { megyei jogú } \\
\text { város }\end{array}$} & Cégek száma & 10 & 4 & 3 & 1 & 5 & 23 \\
\hline & & $\% *$ & $43,5 \%$ & $17,4 \%$ & $13,0 \%$ & $4,3 \%$ & $21,7 \%$ & $100 \%$ \\
\hline & \multirow{2}{*}{ község } & Cégek száma & 20 & 5 & 4 & 4 & 17 & 50 \\
\hline & & $\% *$ & $40,0 \%$ & $10,0 \%$ & $8,0 \%$ & $8,0 \%$ & $34,0 \%$ & $100 \%$ \\
\hline \multirow{2}{*}{\multicolumn{2}{|c|}{ Összesen }} & Cégek száma & 53 & 19 & 14 & 9 & 41 & 136 \\
\hline & & $\% *$ & $39,0 \%$ & $14,0 \%$ & $10,3 \%$ & $6,6 \%$ & $30,1 \%$ & $100 \%$ \\
\hline
\end{tabular}


1. ábra: A gazdasági társaságok likviditása (\%)

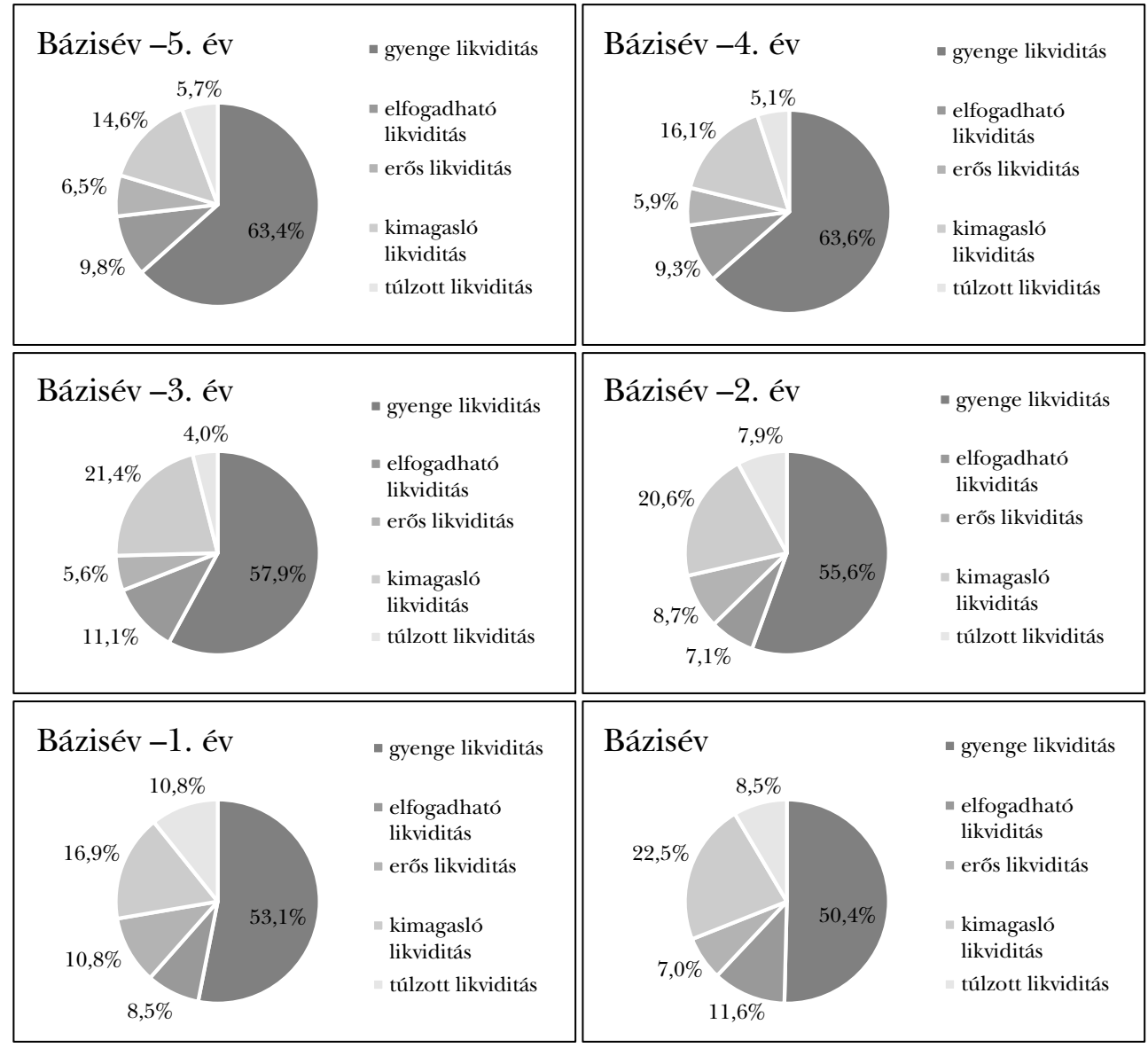

Forrás: Saját szerkesztés a beszámolók alapján

így is elmondható, hogy számuk jelentôs, valamennyi évben 50 százalék feletti volt a gyenge likviditású vállalatok aránya, azaz a vizsgált vállalatok több mint 50 százalékánál állt fenn a fizetésképtelenség veszélye.

\section{ÖsszegzÉS}

Összességében elmondható, hogy ahogy a tôkeerôsségi mutató, úgy a likviditási mutató sem támasztotta alá valamennyi cég esetében a csôd bekövetkezésének lehetôségét. Problémaként említhetô azonban, hogy a gazdasági társaságok több mint 60 százaléka (a tevékenység befejezését meg- elôzó 2., 3., 4. és 5. évben) negatív eredményt realizált, az utolsó két évben pedig ez az érték 75 százalék feletti. A fennmaradó 20-25 százalék (melyet Altman modellje is túléloonek ítélt meg) esetében a magyarázat a tevékenység megszüntetése mögött nem a fizetésképtelenség veszélye volt. A kutatási eredmények alátámasztják Lentner (2014) megállapításait, amely alapján a közüzemi vállalkozásoknál megfigyelhető, hogy a finanszírozásra, múködésre nehezedố kockázatok döntố hányada politikai természetú. Ebben az esetben tehát a modellek által nem pontosan jelzett közüzemi cégek megszúnése inkább a politikai akarat függvénye 


\section{Tudományos múhely}

volt, mintsem a gazdálkodás objektív jellemzóinek hatására történt. A vizsgálat során bizonyossá vált, hogy Altman modellje nagyobb arányban jelezte elôre a múködésképtelenség bekövetkezését, míg a brazil és a Karas-modell kevésbé volt képes a csôdkockázatot jelezni. Sok esetben elmondható, hogy a csökkenố rentabilitás vezet a vállalkozási tevékenység megszüntetéséhez.

\section{FELHASZnÁlt IRODALOM}

Altman, Edward I. (1968): Financial Ratios, Discriminant Analysis and the Predicition of Corporate Bankruptcy. The Journal of Finance, Vol. 23, No. 4, 589-609, https://doi.org/10.2307/2978933.

Altman, Edward I. - Baidya, Tara K. N. - Dias, Luis M. R. (1979): Assessing Potential Financial Problems for Firms in Brazil. Journal of International Business Studies, Vol. 10, No. 2, 9-24, https:// doi.org/10.1057/palgrave.jibs.8490787.

Altman, Edward I. (1993): Corporate Financial Distress - Bankruptcy. A Complete Guide to Predicting and Avoiding Distress and Profiting From Bankruptcy. John Wiley \& Sons, Hoboken.

Béhm Imre - Bárczi Judit - Zéman Zoltán (2016): A vállalkozási teljesítmény mérésének mutatói és alkalmazásuk I. Controller Info, 4. évf., 3. sz., 27-36.

Hegedûs, Szilárd (2015): Analysing the Management of Public Utility Companies Owned by Municipalities of Country Rank Between 2009 and 2011. In: Csata, Andrea et al. (eds.): Global Challenges, Local Answers. Challenges in the Carpathian Basin. 11th Annual International Conference on Economics and Business, Sapientia Hungarian University of Transsylvania, Csíkszereda, Románia, 204-212.

Hegedûs Szilárd - Zéman Zoltán (2016): Tókeszerkezeti elméletek érvényesülésének vizsgálata a hazai önkormányzati tulajdonú gazdasági társaságok körében. Statisztikai Szemle, 94. évf., 10. sz., 1032-1049., https://doi.org/10.20311/ stat2016.10.hu1032.

Karas, Michal - Režňáková, Mária (2017): Could the Coefficients Re-Estimation Solve the Industry or Time Specific Issues? International Journal of Eco- nomics and Management Systems, Vol. 2, 206-213, https://doi.org/10.5755/j01.ee.28.2.16353.

Karas, Michal - Režňáková, Mária - Bartoš, Vojtech - Zinecker, Marek (2013): Possibilities for the Application of the Altman Model within the Czech Republic. The 4th International conference on Finance, Accounting and Law (ICFA 13), Crete, 203-208.

Lentner, Csaba (2013a): Enforcement of the Principle of Going Concern: with Special Regard to Public Service Providers. In: Hyránek, Eduard - Nagy, Ladislav (eds.): Zborník Vedeckých Stati: Priebežné výsledky riešenia grantovej úlohy VEGA č. 1/0004/13: Aktuálne trendy a metódy vo finančnom riadení podnikov a ich vplyv na finančnú stabilitu podniku. Vydavatelstvo Ekonóm, Bratislava, 9-17.

Lentner Csaba (2013b): Közpénzügyek és államháztartástan. Nemzeti Közszolgálati Tankönyvkiadó, Budapest.

Lentner Csaba (2014): A vállalkozás folytatása számviteli alapelvének értékelése - profit és közjószág-elóállító gazdálkodóknál I. Számvitel Adó Könyvvizsgálat, 56. évf., 2. sz., 72-74.

Lentner Csaba (2015): A vállalkozás folytatása számviteli alapelvének érvényesülése közüzemi szolgáltatóknál és költségvetési rend szerint gazdálkodóknál - magyar, európai jogi és eszmetörténeti vonatkozásokkal. In: Lentner Csaba (szerk.): Adózási pénzügytan és államháztartási gazdálkodás. Közpénzügyek és államháztartástan II. NKE Szolgáltató Kft., Budapest, 763-783.

Németh Erzsébet - Kolozsi Pál Péter (2015): A közpénzfelhasználás célszerúsége és hatékonysága az Állami Számvevôszék ellenôrzéseinek tükrében. In: Lentner Csaba (szerk.): Adózási pénzügytan és államháztartási gazdálkodás. Közpénzügyek és államháztartástan II. NKE Szolgáltató Kft., Budapest, 153-179.

Zéman Zoltán - Tóth Antal (2015): Az önkormányzatok és közüzemi vállalatok teljesítményértékelése In: Lentner Csaba (szerk.): Adózási pénzügytan és államháztartási gazdálkodás. Közpénzügyek és államháztartástan II. NKE Szolgáltató Kft., Budapest, 829-853.

Zéman Zoltán (2017): A pénzügyi controlling kockázatcsökkentố szerepe önkormányzati szervezeteknél. Pénzügyi Szemle, 62. évf., 3. sz., 294-310. 